\title{
Effect of tif Expression, Irradiation of Recipient and Presence of Plasmid pKM101 on Recovery of a Marker from a Donor Exposed to Ultraviolet Light Prior to Conjugation
}

\author{
By ATTE VON WRIGHT AND BRYN A. BRIDGES* \\ MRC Cell Mutation Unit, University of Sussex, Falmer, Brighton BN1 9QG \\ (Received 16 January 1980; revised 24 March 1980)
}

\begin{abstract}
To detect the effect of the postulated inducible error-prone repair system ('SOS repair') on the bacterial chromosome, an Hfr Escherichia coli strain JC5088 recA was u.v.-irradiated immediately before mating it with recipients in which SOS repair was supposed to be functioning either through tif expression, u.v. irradiation or the presence of plasmid pKM101. The recombinant yields of these crosses were compared with those obtained in corresponding crosses with recipients in which SOS repair either was not induced or was totally eliminated by the lexA mutation. No difference in marker recovery efficiency could be detected between these two sets of recipients and thus no induced repair process acting on donor DNA could be demonstrated. The possible reasons for this finding are discussed.
\end{abstract}

\section{INTRODUCTION}

The enhanced survival of u.v.-irradiated bacteriophage (Weigle reactivation) when plated on a u.v.-irradiated Escherichia coli host (Weigle, 1953) has been postulated to reflect the activity of an inducible repair system ('SOS repair') acting on irradiated DNA (Radman, 1974, 1975). According to this hypothesis, various treatments affecting DNA metabolism, such as u.v. irradiation, thymine starvation, nalidixic acid, chemical mutagens, etc., may trigger an inducible error-prone DNA repair system dependent upon the $\operatorname{rec} A^{+}$and $\operatorname{lex} A^{+}$ genes, which is responsible not only for the increased survival of irradiated phage but also for phage and bacterial mutagenesis. One of the most convincing pieces of evidence in support of this theory is the existence of a certain group of mutants (tif) altered at the recA locus of Escherichia coli. These mutants, when grown at $43^{\circ} \mathrm{C}$, express constitutively some of the supposed 'SOS functions', such as increased survival of irradiated phage lambda and high mutability of both phage and bacterial genes (Castellazzi et al., 1972; Witkin, 1974). SOS repair is also assumed to be constitutively expressed in bacterial strains harbouring an ampicillin resistance plasmid pKM101 (Mortelmans \& Stocker, 1976). These strains show high spontaneous and induced mutability and are also more resistant to u.v. radiation than corresponding isogenic strains without the plasmid.

There has been, however, no direct evidence of any inducible repair system acting to enhance the survival of the bacterial chromosome and the theory is largely based on phage experiments. To provide a more direct test it is necessary to arrange a system analogous to that of Weigle reactivation of bacteriophage, whereby the bacterial chromosome may be damaged outside the cell in which SOS induction takes place. We have therefore attempted to detect possible SOS repair of the bacterial chromosome by mating a u.v.-irradiated donor with recipients in which the repair system was activated either by expression of the tif 
mutation, by u.v. irradiation of the recipient before the mating, or by the presence of the plasmid pKM101. The number of recombinants obtained from these crosses was compared with that obtained from corresponding crosses with near-isogenic tif $^{+}$, unirradiated, or non-plasmid-carrying recipients.

\section{METHODS}

Bacteria. Escherichia coli JC5088 rec A str ${ }^{+} \mathrm{Hfr}$ (Green et al., 1971) was used as the donor in all the experiments. Its origin of transfer is at $62 \mathrm{~min}$ and the his gene (at $44 \mathrm{~min}$ ) enters after about $20 \%$ of the genome has been introduced. The strains JM12 tif-1 (Castellazzi et al., 1972), AB1157 (Howard-Flanders et al., 1966) with or without the plasmid pKM101, and PAM5717 lexA (Donch et al., 1968) were used as recipients. All the recipient strains carry thr leu thi pro his arg str lac gal as additional markers. The plasmid pKM101 was transferred into AB1157 from an Escherichia coli B strain CM891 uvrA trp, constructed previously in this laboratory (Doubleday et al., 1977). The bacteria were grown routinely in L broth [containing (per litre): $5 \mathrm{~g}$ glucose, $10 \mathrm{~g}$ Bacto Tryptone, $5 \mathrm{~g}$ Bacto yeast extract, $5 \mathrm{~g} \mathrm{NaCl} ; \mathrm{pH} 7.0$ ], in which the mating experiments were also performed. For each experiment overnight cultures of the strains were diluted into fresh medium. The donor was grown with aeration into the exponential growth phase (around $1 \times 10^{8}$ to $2 \times 10^{8} \mathrm{ml}^{-1}$ ) and the recipients to late-exponential phase (around $10^{9} \mathrm{ml}^{-1}$ ). The incubation temperature was $32^{\circ} \mathrm{C}$ for all the strains if JM12 was used in the experiment, otherwise it was $37^{\circ} \mathrm{C}$.

Transfer of plasmid pKM101 into E. coli AB1157. Portions ( $1.0 \mathrm{ml})$ of overnight cultures of both CM891 and $\mathrm{AB} 1157$ were mixed together with $10 \mathrm{ml}$ fresh medium. After overnight incubation at $37^{\circ} \mathrm{C}$ the mating mixture was diluted $10^{-5}$ into buffer and plated on Davis-Mingioli (1950) minimal agar supplemented with Casamino acids (Difco, $4.0 \mathrm{~g}^{-1}$ ) and ampicillin $\left(0.2 \mathrm{~g} \mathrm{l}^{-1}\right)$. The plates were incubated at $37^{\circ} \mathrm{C}$ for $48 \mathrm{~h}$. Several colonies were then picked, cultured and tested for both spontaneous and u.v.-induced mutability. The strain that showed the highest spontaneous and induced mutation frequency was also tested for u.v. resistance and found to be about twice as resistant as the parent AB1157. This strain was designated CM1112 and subsequently used as one of the recipients.

Ultraviolet irradiation of the donor. Exponentially growing cells were centrifuged and suspended in phosphate buffer. This suspension was divided into portions which were then u.v.-irradiated with different doses. Irradiated cells were again centrifuged and resuspended in fresh medium.

Induction of SOS functions in the recipients. In the temperature-sensitive strain JM12, tif expression was induced by performing the crosses at $43^{\circ} \mathrm{C}$. In the strain $\mathrm{AB} 1157$, SOS functions were triggered by irradiating the cells (suspended in $\left.0.01 \mathrm{M}-\mathrm{MgSO}_{4}\right)$ with u.v. light $\left(30 \mathrm{~J} \mathrm{~m}^{-2}\right)$ immediately before mating. The success of the induction was checked by microscopic examination of the JM12 cells to detect the characteristic filamentous growth (Kirby et al., 1967) after 2 to $3 \mathrm{~h}$ growth at $43^{\circ} \mathrm{C}$ and, in case of the strain $\mathrm{AB} 1157$, by plating u.v.-irradiated phage lambda with either u.v.-irradiated or unirradiated bacteria to detect Weigle reactivation.

In the plasmid-carrying strain CM1112 the expression of SOS function was assumed to be constitutive and consequently no special inducing treatment was given.

Mating. Recipient cultures were centrifuged and suspended in fresh medium (one-third of the original volume). Donor and recipient cultures were then mixed in a ratio of 1 to 4 . With the strain JM12 as recipient this mating mixture was, in some experiments, divided into three subcultures one of which was left as a control, one supplemented with adenine $\left(75 \mu \mathrm{g} \mathrm{ml}^{-1}\right)$ to enhance tif expression and one with guanosine and cytidine $\left(100 \mu \mathrm{g} \mathrm{ml}^{-1}\right)$ to suppress it (Witkin, 1974). After $45 \mathrm{~min}$ the mating was interrupted by vigorous agitation and the cells were plated on selective media [Davis-Mingioli minimal medium supplemented with threonine $\left(20 \mu \mathrm{g} \mathrm{ml}^{-1}\right)$, leucine $\left(10 \mu \mathrm{g} \mathrm{ml}^{-1}\right)$, proline $\left(10 \mu \mathrm{g} \mathrm{ml}^{-1}\right)$, arginine $\left(20 \mu \mathrm{g} \mathrm{ml}^{-1}\right)$, thiamin $(0.1 \mu \mathrm{g}$ $\left.\mathrm{ml}^{-1}\right)$ and streptomycin $\left(0.3 \mathrm{mg} \mathrm{ml}{ }^{-1}\right)$; when the mating mixture had contained adenine or guanosine and cytidine, the corresponding additions were also made to the selective medium]. The plates were incubated at $32{ }^{\circ} \mathrm{C}$ for $48 \mathrm{~h}$ and then $h i s^{+}$str recombinants were counted.

\section{RESULTS AND DISCUSSION}

The results are expressed in Fig. 1. Although there were great differences between the recipient strains in their abilities to form recombinants in the crosses, the curves obtained by plotting the numbers of recombinants against u.v. dose given to the donor were almost parallel for each donor-recipient pair. Neither tif expression, u.v. irradiation of the recipient nor the presence of the plasmid pKM101 affected the slope of the curves. Expression of Weigle reactivation in irradiated recipients was confirmed by the observation of enhanced (4- to 9-fold) survival of u.v.-irradiated phage lambda. 


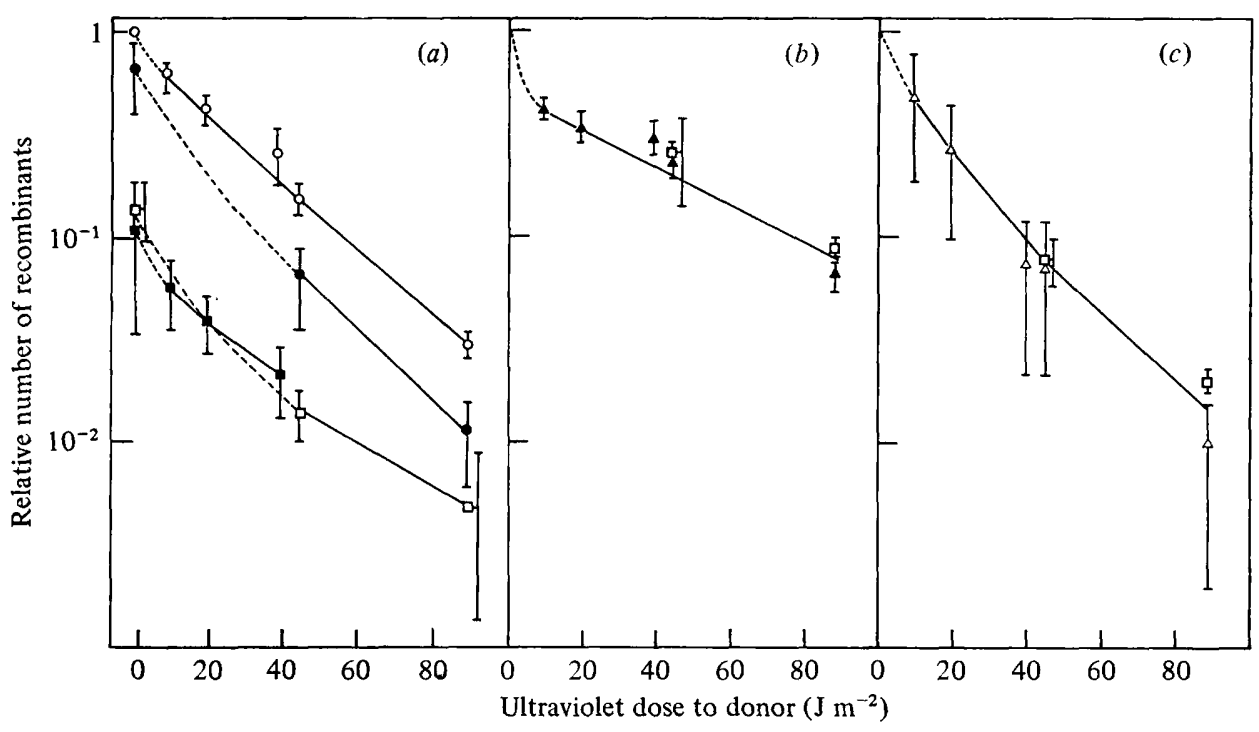

Fig. 1. (a) Effect of tif expression on the ability of recipients to form recombinants in crosses with a u.v.-irradiated donor. The results are expressed as a fraction of the number of recombinants obtained in crosses between an unirradiated donor and a tif-induced recipient (JM12). All the matings were performed at $43^{\circ} \mathrm{C}$ and the selection plates were incubated at that temperature for a further $45 \mathrm{~min}$ before being transferred to $32^{\circ} \mathrm{C}$. $\mathrm{O}, \mathrm{JM} 12 ; \mathrm{O}, \mathrm{JM} 12$ with guanosine and cytidine in the mating medium; $\square, \mathrm{AB} 1157 ; \square$, PAM 5717. The vertical lines represent standard errors of the means of three or more experiments.

(b) Effect of u.v. irradiation of the recipient on the yield of recombinants in crosses with a u.v.irradiated donor. The results are expressed as a fraction of the number of recombinants in crosses with unirradiated donors and recipients. $\square$, Unirradiated AB1157; $\boldsymbol{\Delta}$, u.v.-irradiated AB1157 (dose $30 \mathrm{~J} \mathrm{~m}^{-2}$ ).

(c) Effect of the presence of plasmid pKM101 in the recipient on the yield of recombinants in crosses with a u.v.-irradiated donor. The results are expressed as a fraction of the number of recombinants in crosses with unirradiated donors and non-plasmid-carrying recipients. $\square, \mathrm{AB} 1157$; $\triangle$, CM1112 (i.e. AB1157 carrying the plasmid pKM101).

Expression of tif in JM12 bacteria at $43{ }^{\circ} \mathrm{C}$ was clearly shown in these experiments by the development of the characteristic filamentation and by an increase in the number of recombinants with both irradiated and unirradiated donors compared with AB1157. Guanosine and cytidine, which are inhibitors of tif expression, somewhat reduced the number of recombinants in JM12. The results are in agreement with a previous report which noted an increase in the number of recombinants in tif recipients (Lloyd, 1978). Irradiation of the recipient did not affect the number of recombinants obtained. The plasmid pKM101 did not greatly affect the number of recombinants, but their growth was somewhat slower compared with the rest of the recipients. Our data therefore provide no evidence for an inducible SOS repair system acting on incoming donor DNA that can enhance the recovery of a donor marker as a recombinant.

We have considered the possibility that repair systems might have been induced indirectly by the irradiated donor DNA itself. This possibility seems to be excluded, however, by the result with PAM5717. This lexA derivative of AB1157 would not be expected to express any of the SOS inducible functions. LexA strains do not show tif phenomena (Castellazzi et al., 1973), Weigle reactivation (Defais et al., 1971) or pKM101-mediated repair (Walker, 1977).

The incoming donor chromosome is, of course, to some extent unrepresentative of the complete bacterial chromosome as it normally exists, most chiefly in that it is believed to enter as a single strand of DNA. Weigle reactivation is, nonetheless, able to operate on single-stranded phage DNA (Ono \& Shimazu, 1966) and one might a priori have expected 
the u.v.-irradiated donor strand to be a valid homologue of this. The fact that the presence or absence of functional excision repair in the recipient has no influence on the yield of recombinants with Flac ${ }^{+}$donor DNA (Howard-Flanders et al., 1968) argues that irradiated donor DNA is not integrated into the recipient chromosome as an unrepaired single strand. It is clear from the data of Howard-Flanders et al. (1968), however, that a considerable amount of the incoming strand repair must occur in the recipient, presumably to generate a continuous duplex molecule. One implication of our negative finding is that this does not occur by a lex $A^{+}$-dependent inducible process such as SOS repair.

There seems to be no reason why a constitutive recombinational process, similar to that postulated by Rupp \& Howard-Flanders (1968) to occur at daughter strand gaps produced during replication of u.v.-irradiated DNA, should not be able to act on donor DNA. The lexA mutation, although depressing daughter strand repair, does not constitute an absolute block. Be that as it may, our results require the conclusion that inducible SOS repair is either non-existent or insignificant in extent compared with constitutive processes leading to the recovery of viable recombinants from u.v.-irradiated donor DNA. It may well be that this difference from what is observed with irradiated bacteriophage is a reflection of the fact that phage does not need to undergo a recombination step in order to survive and be detected. To this extent, therefore, the Hfr system that we have used may be an imperfect model.

\section{REFERENCES}

Castellazzi, M., George, J. \& Buttin, G. (1972). Prophage induction and cell division in $E$. coli. I. Further characterization of the thermosensitive mutation tif-1, whose expression mimics the effect of UV-irradiation. Molecular and General Genetics 119, 139-152.

Castellazzi, M., George, J. \& Buttin, G. (1973). Prophage induction and cell division in E. coli. II. Linked $(r e c A, z a b)$ and unlinked (lex) suppressors of tif-mediated induction and filamentation. Molecular and General Genetics 119, 153174.

Davis, B. D. \& Mingioli, E. S. (1950). Mutants of Escherichia coli requiring methionine or vitamin B12. Journal of Bacteriology 60, 17-28.

Defais, M., Fauquet, P., Radman, M. \& Errera, M. (1971). Ultraviolet reactivation and ultraviolet mutagenesis of lambda in different genetic systems. Virology 43, 495-503.

Donch, J., Green, M. H. L. \& Greenberg, J. (1968). Interaction of the exr and lon genes in Escherichia coli. Journal of Bacteriology 96, 17041710.

Doubleday, O. P., Green, M. H. L. \& Bridges, B. A. (1977). Spontaneous and ultraviolet-induced mutation in Escherichia coli: interaction between plasmid and tif-1 mutator effects. Journal of General Microbiology 101, 163-166.

Green, M. H. L., Bridges, B. A. \& Riazuddin, S. (1971). Effect of $\gamma$-radiation on the donor ability of recA and $\operatorname{rec} A^{+}$strains of Escherichia coli. Journal of General Microbiology 67, 63-68.

Howard-Flanders, P., Boyce, R. P. \& Theriot, L. (1966). Three loci in Escherichia coli K-12 that control the excision of pyrimidine dimers and other mutagen products from DNA. Genetics 53, 1119-1136.

Howard-Flanders, P., Rupp, W.D., Wilkins, B. M. \& Cole, R. S. (1968). DNA replication and recombination after UV irradiation. Cold Spring Harbor Symposia on Quantitative Biology 33, 195-205.

Kirby, E. P., Jacob, F. \& Goldthwait, D. A. (1967). Prophage induction and filament formation in a mutant strain of Escherichia coli. Proceedings of the National Academy of Sciences of the United States of America 58, 1903.

Lloyd, R. G. (1978). Hyper-recombination in Escherichia coli K-12 mutants constitutive for protein X synthesis. Journal of Bacteriology 134, 929-935.

Mortelmans, K. E. \& Stocker, B. A. D. (1976). Ultraviolet light protection, enhancement of ultraviolet light mutagenesis, and mutator effect of plasmid R46 in Salmonella typhimurium. Journal of Bacteriology 128, 271-282.

ONO, J. \& ShImaZu, Y. (1966). Ultraviolet reactivation of a bacteriophage containing a singlestranded deoxyribonucleic acid as a senetic element. Virology 29, 295-301.

Radman, M. (1974). Phenomenology of an inducible mutagenic DNA repair pathway in Escherichia coli: SOS repair hypothesis. In Molecular and Environmental Aspects of Mutagenesis, pp. 355367. Edited by L. Prakash, F. Sherman, M. W. Miller, C. W. Lawrence \& H. W. Taber. Springfield, Illinois: C. C. Thomas.

RADMAN, M. (1975). SOS-repair hypothesis: Phenomenology of an inducible DNA repair which is accompanied by mutagenesis. In Molecular Mechanisms for Repair of DNA, pp. 355-367. Edited by P. C. Hanawalt \& R. B. Setlow. New York: Plenum Press.

Rupp, W. D. \& Howard-Flanders, P. (1968). Discontinuities in the DNA synthesized in an excision-defective strain of Escherichia coli following ultraviolet irradiation. Journal of Molecular Biology 31, 291-304. 
WALker, G. C. (1977). Plasmid (pKM101) mediated enhancement of repair and mutagenesis: dependence on chromosomal genes in Escherichia coli K-12. Molecular and General Genetics 152, 93-103. WEIGLE, J. J. (1953). Induction of mutation in a bacterial virus. Proceedings of the National Academy of Sciences of the United States of America 39, 628- 636.
Witkin, E. M. (1974). Thermal enhancement of ultraviolet mutability in a tif-1 uvrA derivative of Escherichia coli $\mathrm{B} / \mathrm{r}$ : evidence that ultraviolet mutagenesis depends upon an inducible function. Proceedings of the National Academy of Sciences of the United States of America 71, 1930-1934. 